\section{Susceptibility of Tomato Cultivars to Internal and External Tomato Irregular Ripening}

\author{
Charles A. Powell and Peter J. Stoffella \\ Agricultural Research and Education Center, Institute of Food and Agricultural \\ Sciences, University of Florida, 2199 South Rock Road, Fort Pierce, \\ FL 34945-3138 \\ Additional index words. Lycopersicon esculentum, sweet potato whitefly, Bemisia \\ argentifolii
}

Tomato (Lycopersicon esculentum Mill.) irregular ripening (TIR) is associated with the feeding of Bemisia argentifolii Bellows and Perrin [silverleaf whitefly (SLWF); formerly the sweet potato whitefly] (Maynard and Cantliffe, 1989). The disorder is characterized by green, white, or pink streaks or blotches on the exterior of fruit that may disappear when fruit become fully ripe (Powell and Stoffella, 1995). Interior TIR symptoms consist of white or yellow discoloration of the fruit pericarp. Tomatoes with external symptoms almost always have internal symptoms, but those without external symptoms may still have a high incidence of internal symptoms (Powell and Stoffella, 1995). Both types of symptoms reduce fruit quality and lower returns for tomatoes sold for the fresh market. In tomato fields with severe infestation of SLWF, $>50 \%$ of the fruit can have internal TIR symptoms (Powell and Stoffella, 1995).

Strategies to reduce the incidence of TIR have focused largely on management of the SLWF. In an experiment by Powell and Stoffella (1993), weekly applications of the insecticide $6,7,8,9,10,10$-hexachloro1,5,5a,6,9,9a-hexahydro-6,9-methano-2,4,3benzodioxathiepin 3-oxide (endosulfan) reduced internal TIR incidence from $52 \%$ to $22 \%$. Cultural practices, such as reflective aluminum mulch (Powell and Stoffella, 1993) or cold storage before ripening (Powell and Stoffella, 1995), have not significantly reduced the incidence of TIR.

To our knowledge, no information about the relative susceptibility of commercially grown tomato cultivars to TIR has been reported. Field experiments were conducted to compare nine cultivars important in Florida

Received for publication 27 Jan. 1995. Accepted for publication 14 May 1995. Florida Agricultural Expt. Station Journal Series no. R-03212. We thank Mike Fleming and Jack Cordy for technical assistance. The cost of publishing this paper was defrayed in part by the payment of page charges. Under postal regulations, this paper therefore must be hereby marked advertisement solely to indicate this fact. for their development of external and internal TIR symptoms during heavy SLWF infestations.

Five-week-old transplants of 'Agriset 761', 'Bonita', 'Cobia', 'Colonial', 'Merced', 'Solar Set', 'Solimar', 'Sunmaster', and 'Sunny' were planted on polyethylene-covered raised beds (Hochmuth, 1988) on 13 Sept. 1993 (fall season) and 7 Mar. 1994 (spring season) at the Agricultural Research and Education Center, Fort Pierce, Fla. Soil type classification, bed preparation, disease control, and fertilization practices were as described by Powell and Stoffella (1993).

A randomized compete-block design with four replications of each cultivar was used. The experimental area consisted of four rows, spaced $2.1 \mathrm{~m}$ apart (center to center), each row serving as a replication, with 12 plants of each of the nine cultivars randomized within each row. Transplants were spaced $61 \mathrm{~cm}$ apart in the center of each bed (7687 plants/ha). Five weeks after transplanting, SLWF were introduced by placing 27 pots (3.7 liter), containing greenhouse-grown tomato plants infested with SLWF, per row at 3-m intervals (Powell and Stoffella, 1995). No insecticides were applied to the experimental area. Adult SLWF populations were monitored weekly using $7.5 \times 7.5$ $\mathrm{cm}$, yellow, sticky boards (Great Lakes IPM, Vestaburg, Mich.) (Powell and Stoffella, 1993).

Red-ripe tomatoes were harvested on 29 Dec. 1993 and 3, 10, 19, and 26 Jan. 1994 for the fall experiment and 26 May and 2 and 6 June 1994 for the spring experiment. Each fruit was evaluated for external TIR, then sliced in half equilaterally and evaluated for internal TIR. Data (percentages) were subjected to analysis of variance, and significant cultivar means were separated by Duncan's multiple range test at $P \leq 0.05$.

Each cultivar exposed to SLWF in the fall and spring experiments developed a high incidence of external and internal TIR. The percentage of tomatoes with internal symptoms was higher than that with external symptoms. For the fall experiment, the external and internal TIR for the nine cultivars ranged from $12 \%$ to $37 \%$ and $39 \%$ to $69 \%$, respectively; how-
Table 1. Incidence of external and internal irregular ripening in several fresh-market tomato cultivars, Fort Pierce, Fla., Spring 1994.

\begin{tabular}{lcc}
\hline \hline & \multicolumn{2}{c}{ Irregular ripening $(\%)^{\mathrm{z}, \mathrm{y}}$} \\
\cline { 2 - 3 } Cultivar & External & Internal \\
\hline Agriset 761 & $13.4 \mathrm{a}-\mathrm{c}$ & 55.5 \\
Bonita & $23.0 \mathrm{a}$ & 52.7 \\
Cobia & $22.4 \mathrm{a}$ & 51.2 \\
Colonial & $6.4 \mathrm{c}$ & 47.8 \\
Merced & $14.7 \mathrm{a}-\mathrm{c}$ & 38.8 \\
Solar Set & $24.3 \mathrm{a}$ & 44.0 \\
Solimar & $15.9 \mathrm{a}-\mathrm{c}$ & 33.4 \\
Sunmaster & $19.7 \mathrm{ab}$ & 37.2 \\
Sunny & $10.5 \mathrm{bc}$ & 48.5 \\
\hline
\end{tabular}

${ }^{2}$ Percentages are based on 100 fruit for each of four replications.

'Mean separation by Duncan's multiple range test at $P \leq 0.05$; internal, no significant differences.

ever, cultivar differences were not significant. For the spring experiment, the external and internal TIR ranged from $6 \%$ to $24 \%$ and $33 \%$ to $55 \%$, respectively. For the spring experiment, the differences among the means for internal TIR were not significant, but there were some significant differences for external TIR (Table 1). In particular, 'Colonial' had a lower incidence of external TIR than 'Bonita', 'Cobia', 'Solar Set', and 'Sunmaster'. 'Solar Set', 'Bonita', and 'Cobia' had the highest and about equal incidence of external TIR.

SLWF counts taken from each cultivar (mean $=174$ and 391 adults per week in the fall and spring, respectively, at the conclusion of the experiment) did not differ significantly among cultivars, suggesting that differences among them are not due to the number of SLWF feeding. These SLWF weekly population curves were similar in natural heavy infestations (Powell and Stoffella, 1993) (data not shown).

Our results suggest a lack of adequate tolerance to TIR in all of the cultivars evaluated. When infested with SLWF in the field, each cultivar developed a high incidence of external and internal TIR that would have resulted in significant loss of yield and quality of fresh-market fruit. However, differences among the cultivars in development of external TIR symptoms may be a factor to consider when selecting a cultivar for fresh-market fruit production in a region where SLWF are prevalent.

\section{Literature Cited}

Hochmuth, G.J. 1988. Tomato production guide for Florida. Florida Coop. Ext. Serv. Circ. 986.

Maynard, D.N. and D.J. Cantliffe. 1989. Squash silverleaf and tomato irregular ripening: New vegetable disorders in Florida. Fla. Coop. Ext. Serv. IFAS VC-37.

Powell, C.A. and P.J. Stoffella. 1993. Influence of endosulfan sprays and aluminum mulch on sweetpotato whitefly disorders of zucchini squash and tomatoes. J. Prod. Agr. 6:118-121.

Powell, C.A. and P.J. Stoffella. 1995. Culling tomatoes with external symptoms of irregular ripening is of limited benefit. HortScience 30:316317. 